\title{
DÜBLIN
}

Technological University Dublin ARROW@TU Dublin

\section{The Tenderisation of Shin Beef Using a Citrus Juice Marinade}

\author{
Roisin Burke \\ Technological University Dublin, roisin.burke@tudublin.ie \\ Frank Monahan \\ University College Dublin, Ireland, frank.monahan@ucd.ie
}

Follow this and additional works at: https://arrow.tudublin.ie/tfschafart

Part of the Agribusiness Commons, Arts and Humanities Commons, and the Food Studies Commons

\section{Recommended Citation}

Burke, R.M. and Monahan, F.J. (2003). The tenderisation of shin beef using a citrus juice marinade. Meat Science, 63 (2), pp.161-168. doi:10.1016/S0309-1740(02)00062-1

This Article is brought to you for free and open access by the School of Culinary Arts and Food Technology at ARROW@TU Dublin. It has been accepted for inclusion in Articles by an authorized administrator of ARROW@TU Dublin. For more information, please contact arrow.admin@tudublin.ie, aisling.coyne@tudublin.ie, gerard.connolly@tudublin.ie.

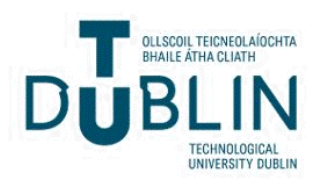


Dublin Institute of Technology

ARROW@DIT

Articles

Conservatory of Music and Drama

2003-2

\section{The tenderisation of shin beef using a citrus juice marinade}

Roisin Burke

Frank Monahan

Follow this and additional works at: https://arrow.dit.ie/aaconmusart

Part of the Food Science Commons

This Article is brought to you for free and open access by the Conservatory of Music and Drama at ARROW@DIT. It has been accepted for inclusion in Articles by an authorized administrator of ARROW@DIT. For more information, please contact yvonne.desmond@dit.ie, arrow.admin@dit.ie, brian.widdis@dit.ie. 


\title{
Meat Science
}

Volume 63, Issue 2, February 2003, Pages 161-168

\section{The tenderisation of shin beef using a citrus juice marinade}

\author{
Author links open overlay paneIR.M.Burke'F.J.Monahan
}

Show more

https://doi.org/10.1016/S0309-1740(02)00062-1Get rights and content

\begin{abstract}
The effectiveness of organic acids (acetic, citric, lactic) and a citrus juice marinade as tenderising agents in shin beef muscle was investigated. At $0.2 \mathrm{M}$, citric acid was more effective as a tenderising agent than acetic or lactic acid. Immersion of shin beef strips in citric acid (0-0.05 M) showed that a significant tenderising effect was obtained above a concentration of $0.013 \mathrm{M}$. When shin beef strips were immersed in the citrus juice marinade (31\% orange juice, 31\% lemon juice, 38\% distilled water) mean $\mathrm{pH}$ decreased from 5.7 to 3.1 and mean sample weight increased by $\sim 65 \%$. The mean Warner-Bratzler shear force value decreased from 178 to $44 \mathrm{~N} \mathrm{~cm}^{-2}$ following marination while mean sensory analysis scores for tenderness and juiciness increased following marination. A mean total collagen content of $1.4 \mathrm{~g} / 100$ $\mathrm{g}$ was recorded in shin beef of which $9 \%$ was soluble in unmarinated samples and $29 \%$ was soluble in marinated samples. The results indicated that the tenderisation of beef samples using a citrus juice marinade could be attributed to marinade uptake by muscle proteins and also to solubilisation of collagen.
\end{abstract}

